Boise State University

ScholarWorks

Political Science Faculty Publications and

Presentations

Department of Political Science

9-1-2010

Exploring the Links Between Party and Appointment: Canadian Federal Judicial Appointments from 1989 to 2003

Lori Hausegger

Boise State University

Troy Riddell

University of Guelph

Matthew Hennigar

Brock University

Emmanuelle Richez

McGill University 


\title{
Exploring the Links between Party and Appointment: Canadian Federal Judicial Appointments from 1989 to 2003
}

\author{
LORI HAUSEgGer Boise State University \\ TROY RIDDELL University of Guelph \\ MatTHEW HenNigar Brock University \\ EMMANUELLE Richez McGill University
}

In their study of federal judicial appointments in Canada from 1984 to 1988, Peter Russell and Jacob Ziegel indicated that one of the purposes of their study was to "establish the basis for a future comparison between the judicial appointments made before the introduction of the ... judicial advisory committees and the appointments made after them" (1991: 8). Before the establishment of these screening committees, Russell and Ziegel found significant patronage existed in judicial appointments. Indeed, despite the Mulroney government's election pledge to reduce patronage, nearly half of the federal judicial appointments made between 1984 and 1988 had some connection to the governing Progressive Conservative party. Russell and Ziegel found, moreover, that the appointees for whom they discovered partisan connections also tended to be rated as lower quality appointments than appointees with no known political affiliation. How-

\footnotetext{
Acknowledgments: This project was supported by a grant from the Social Sciences and Humanities Research Council of Canada and by a Faculty Research Program grant from the Canadian Embassy. We thank the respondents to our survey and the CJPS reviewers for their helpful comments.
}

Lori Hausegger, Department of Political Science, Boise State University, 1900 University Dr., Boise, ID 83725-1935, lorihausegger@boisestate.edu.

Troy Riddell, Department of Political Science, University of Guelph, Guelph, ON NIG 2W1, riddell@uoguelph.ca

Matthew Hennigar, Department of Political Science, Brock University, 500 Glenridge Avenue, St. Catharines, ON L2S 3A1, matthew.hennigar@brocku.ca

Emmanuelle Richez, Department of Political Science, McGill University, Rm. 414, Leacock Building, 855 Sherbrooke St. West, Montreal, Quebec H3A 2T7, emmanuelle. richez@mail.mcgill.ca 
ever, Russell and Ziegel's data end in 1988 and a full comparison has yet to be made between the pre-committee appointments they studied and those made after the screening committees were introduced.

This article undertakes the comparison envisioned by Russell and Ziegel by examining the political backgrounds of appointees from 1989 to 2003 - a time period that encompasses Mulroney's second term as prime minister as well as ten years of Chrétien's time as prime minister ${ }^{1}$ while also, more generally, assessing the impact of the changes to federal judicial appointments announced in 1988. Did the screening committees reduce the relevance of political connections in the federal judicial appointments process or have patronage appointments continued unabated? Have the screening committees affected the perceptions of the appointments process generally, and the quality of individual federal judicial appointments?

These are important issues, given the increasingly influential role that courts play in the governing process and the relatively high reliance of courts, compared to other institutions, on public and elite support to undergird their authority. At an individual level the appointment process can be more or less fair to those applying to become a judge, and people and organizations can be impacted profoundly by the types of judges put on the bench, both in terms of how judges treat them and by how they decide cases.

The next section of the article describes briefly the federal judicial selection process and the findings of earlier studies. The article then outlines the research methods used for our current study before discussing our results and their implications. We conclude that political connections continued to play an important role in who was selected for a judicial appointment after the introduction of the screening committees in 1988, though the new process may have worked to prevent (for the most part) the politically motivated appointment of completely unqualified individuals. Our findings also suggest that the relevance of patronage varied by region and interacted with other "political" factors, such as group representation on the bench. The article concludes with some thoughts about potential changes to the appointment system with reference to how other jurisdictions negotiate the complex interplay between judicial appointments and judicial independence and, more generally, the relationship between the judiciary and other actors in the overall scheme of governance.

\section{Background}

\section{Historical}

The Constitution Act, 1867 provides that section 96 judges shall be appointed by the Governor General though, in practice, this power is exer- 


\begin{abstract}
Studies of federal judicial appointments made before 1988 discovered significant partisan ties between judicial appointees and the governments appointing them. In 1988, in response to criticism of these "patronage appointments," the Mulroney government introduced screening committees to the process. This article explores the impact of these committees. Using information gained from surveys of legal elites, we trace the minor and major political connections of federal judicial appointees from 1989 to 2003 in order to determine whether patronage has continued despite the reform to the process. We discover that political connections continued to play an important role in who was selected for a judicial appointment. However, these connections were not quite as common as those found before 1988, and the new process does appear to have prevented the politically motivated appointment of completely unqualified candidates. Interestingly, our findings also suggest that the impact of patronage varies by region and interacts with other, newer influences, in particular, concerns for group representation on the bench. The paper concludes by briefly discussing these results in the context of the relationship between judicial selection and politics with a comparative perspective.
\end{abstract}

Résumé. Les études sur les nominations judiciaires fédérales réalisées avant 1988 ont découvert des liens partisans étroits entre les juges nommés à la cour et les gouvernements les nommant. En 1988, en réponse aux critiques sur le favoritisme entourant les nominations, le gouvernement Mulroney a introduit des comités d'évaluation dans le processus. Cet article explore l'impact de ces comités. En utilisant de l'information recueillie lors de sondages menés auprès de la communauté légale, nous retraçons les connexions politiques mineures et majeures des attributaires judiciaires fédéraux de 1989 à 2003 en vue de déterminer si le favoritisme a persisté malgré la réforme du système. Nous découvrons que les connexions politiques continuent à jouer un rôle important dans la sélection des juges. Toutefois, ces connexions ne sont pas aussi importantes que celles qu'on a identifiées avant 1988 et le nouveau processus semble avoir réussi à prévenir les nominations partisanes de candidats entièrement non qualifiés. Les résultats de notre recherche suggèrent également que l'effet du favoritisme varie par région et dépend aussi d'autres facteurs plus nouveaux, en particulier le souci de représentation de certains groupes au sein de la magistrature. L'article conclut en discutant brièvement ces résultats dans le contexte de la relation entre la sélection judiciaire et la politique dans une perspective comparative.

cised by the minister of justice (in consultation with the cabinet) and, in the case of "chief justices," by the prime minister. Section 101 of the Constitution Act, 1867 gives the federal government the authority to establish a general court of appeal and other courts that it deems necessary. The legislation that established the s.101 courts provides that judges shall be appointed by order in council; in reality, as with the s. 96 courts, this power is exercised by the minister of justice and the prime minister. Historically, patronage played a very significant role in federal judicial appointments. The Canadian Bar Association, in an effort to improve the appointment process, established the National Committee on the Judiciary in 1967 to screen the names of judicial candidates forwarded by the minister of justice. In the early 1970s, ministers of justice began to use special advisors to accumulate information about prospective candidates from judges, members of the law profession and provincial attorneys general.

The system, however, still allowed for patronage to play a considerable role in the appointment process. This was amply demonstrated by sev- 
eral patronage appointments made at the end of the Trudeau/Turner years, which generated considerable criticism and brought the appointment process under greater scrutiny, most notably by the Canadian Bar Association's McKelvey Committee. Based on interviews with federal and provincial officials, judges and lawyers, the committee concluded that partisan considerations played a predominant influence in s.96 appointments in the Atlantic provinces and Saskatchewan, and were significant in Alberta and Manitoba. Respondents in BC, Ontario and Quebec provided a more mixed assessment of the role of patronage, which suggested that patronage was not as significant a factor in appointments, though the importance of party affiliation varied to some degree depending on the federal minister of justice (Canadian Bar Association, 1985: 37-40). As for the Federal Court, patronage was found to have been a "dominant" consideration, with many appointees having been "active supporters of the party in power" (Canadian Bar Association, 1985: 57).

In 1991, Russell and Ziegel published their study of the Mulroney government's judicial appointments from 1984 to 1988, based on questionnaire responses from individuals in law, politics, academia and the media who might have been familiar with the appointees. The results indicated that 24.1 per cent of appointees had "major" involvement with the Conservative party (as a party official, as an active participant in an election or leadership campaign or as a candidate for elected office) and 23.2 per cent had "minor" involvement with the Conservative party (minor constituency work, financial contributions or close personal or professional associations with party leaders). ${ }^{2}$ Involvement with an opposition party was ascribed to 7.1 per cent of appointees (5.3 per cent "major" and 1.8 per cent "minor"). The data show that in the late 1980 s, patronage remained an important factor in the appointment process, particularly in Saskatchewan, Manitoba, New Brunswick, Nova Scotia, and PEI (Russell and Ziegel, 1991: 20). Indeed, a former minister of justice in the Mulroney government, John Crosbie, acknowledged in a media interview that he had appointed Conservative activists to the bench during his tenure as minister (Makin, 2005).

\section{Screening Committee Process}

Following the re-election of the Mulroney government in 1988, Justice Minister Ray Hnatyshyn introduced a new system for appointments to the s.96 courts and the Federal Court. The responsibilities of the Office of the Commissioner for Federal Judicial Affairs were expanded to include soliciting applications from those interested in a federal judicial position and, after checking to see if they met the technical qualifications for the post, referring those names to the advisory committees established in each province and territory to screen the candidates. After a committee rates 
the candidates referred to it, the commissioner is responsible for reporting the assessments back to the minister so that appointments can be made from the list on an ongoing basis. ${ }^{3}$

Until recent changes by the Conservative Harper government, membership on the committees consisted of one representative of the provincial or territorial Law Society; one representative of the provincial or territorial branch of the Canadian Bar Association; one representative of the chief justice of the province or of the senior judge of the territory; one representative of the provincial attorney general or territorial minister of justice; three representatives of the federal minister of justice (two of whom must be non-lawyers) and an ex officio non-voting member from the Office of the Commissioner for Federal Judicial Affairs. ${ }^{4}$ In 2006, the Harper government added a police representative to the committee (a fourth appointment by the federal minister of justice) and made the judicial representative a non-voting chair of the committee.

Committees are asked to assess candidates based on a personal information form filled out by candidates, contact with references provided by the candidate and consultations with others not mentioned by the candidate both inside and outside the legal community. The commissioner notes that interviews with the candidates are often not possible because of the number of applicants that must be screened, but encourages interviews if there are divisions on a committee. Candidates are evaluated by committees on their "professional competence and experience" (such as proficiency in the law, writing and communication skills, awareness of racial and gender issues); "personal characteristics" (ethical standards, fairness, tolerance); and "potential impediments to appointment" (drug or alcohol dependency, health, financial difficulties) (see http://www.fjacmf.gc.ca/appointments-nominations/considerations-eng.html for considerations which apply to an appointment).

When the committee system was established originally, candidates were rated as "qualified" or "not qualified," but in 1991 this was changed to "highly recommended," "recommended" and "unable to recommend" and, at that time, committees were also asked to attach a précis about the candidate. Over the first ten years of the committee system, 1892 applications were "recommended" or "highly recommended" while 2477 applications were rated as "not qualified" or "unable to recommend" (Millar, 2000). ${ }^{5}$ In 2006, the Harper Conservative government revised the ranking system back to a two-tiered system ("recommend" or "unable to recommend").

In the end, discretion over who gets appointed remains with the minister of justice and the prime minister. According to the commissioner, the minister can ask for a reassessment of a candidate and can make further inquiries about a candidate with members of the judiciary or the bar, his or her provincial counterparts, and the chief justice of the court 
to which an applicant is going to be appointed. Until 1999, provincial or territorial judges who wanted to become federal judges were not reviewed by committees, but thereafter nonbinding comments were provided by the committees for such candidates (Millar, 2000). Finally, elevations from the trial court level to the appellate level are not reviewed, and the prime minister has discretion over appointments to the senior administrative positions, such as a chief justice.

\section{Previous Assessments of the Screening Committee Process}

Anecdotal evidence provided since 1988 suggests that political connections have continued to play a role in the appointments process after the introduction of the screening system. For example, in 1998 there was a story published about a friend of then Justice Minister Anne McLellan being appointed in Nova Scotia after the screening committee was asked to reassess its initial finding of "not recommended" (Meek, 1998). Until now, more systematic examinations of the impact of the 1988 screening committees on appointments were confined mostly to tracing whether individuals had donated money to the party in power prior to their appointment by the federal government (Forcese and Freeman, 2005; Schmitz, 2005). In 2008, using a more rigorous method of classifying appointees as "probable" donors than previous studies, we found that 30.6 per cent of appointees from 1989 to 2003 very likely had donated to their appointing party in the five years prior to their appointment. ${ }^{6}$

In that study, we recognized various limitations of looking only at political donations as a proxy for political connections. Relying on such a measure potentially misses other important types of political involvement (from fundraising to running for office) that appointees may have had. Although we believed that it was telling that the governing party almost universally appointed individuals who had donated to them rather than individuals who had donated to an opposition party, not having additional data limited our ability to contend with the possibility that lawyers in general tend to be political creatures who donate to parties (as do law firms). This current research provides greater insight into the backgrounds of appointees and how the system works.

\section{Data Collection}

For our previous project we had collected the names and brief biographical details of judges appointed by the federal government between 1989 and 2003 to the s.96 courts (trial and appeal) in the provinces, as well as to the Federal Court (trial and appeal) and the Tax Court. There were 
856 individuals who received such federal appointments. ${ }^{7}$ Of these judges, 303 were appointed under Prime Minister Mulroney and 553 were appointed under Prime Minister Chrétien. (See the appendix, table A1, for a complete breakdown of the number of appointments made by province and by each prime minister.)

To ascertain the political connections (if any) of the appointees we enlisted the help of senior lawyers and law professors in each province to act as informants. Law professors were contacted if they had significant teaching and/or professional experience (approximately ten years). Senior lawyers who had a significant profile in the legal community were identified through various means, including electronic searches for lawyers who held positions in professional associations, such as provincial law societies and the Canadian Bar Association, lawyers who had been designated Queen's Counsel (QC) and lawyers identified in media stories.

Email requests for participation were sent to potential informants in each province asking them to participate in a web-based survey. The web survey asked respondents to choose an appointee from their province from a drop-down menu. The date and court of appointment were included beside the appointee's name on the drop-down list. ${ }^{8}$ For each appointee, our informants were asked first to provide an assessment of their quality prior to their appointment. The informants were then asked whether the appointee had some association with a political party, including minor constituency work, fundraising, being a senior campaign activist, sitting as a party executive or running for office. Informants were also able to answer that they were "unsure" of an appointee's political background or that the appointee had "no political activity" prior to appointment. If one or more political activities were chosen (with a provincial party or a federal party), the informant was asked to specify with which party the appointee had been associated and was given the opportunity to provide contextual commentary.

The survey then asked informants whether the appointee had any close social connections with a federal cabinet minister, member of parliament, executive member of the governing party or other social connections. The same question was asked about close professional connections. Opportunities were provided for informants to provide contextual commentary about an appointee's close social and professional connections or any such connections with opposition parties.

In addition to providing information about appointees with whom they were familiar, informants were encouraged to provide their general impressions about the judicial appointment process. They were asked to rank how important "political connections" and "social and professional connections" were in the federal appointment process along a five-point scale from Unimportant (1) to Very Important (5). Respondents were then 
asked how the federal judicial appointments system worked in practice and a text box was available for responses. ${ }^{9}$

The survey concluded by asking informants if they would be willing to participate in a confidential telephone conversation to talk about the appointment process in more depth. A total of 173 individuals participated in the survey in ten provinces and we conducted 35 follow-up interviews. The interviews began with rather open-ended questions about the federal appointment system, which gave respondents the opportunity to talk about what they believed were the most important features of the system. Follow-up questions were asked about particular issues arising from this general discussion. We then asked interviewees to provide information about appointees with whom they were familiar but did not fill out surveys for online because of time constraints.

As discussed below, we classified individuals using two different classificatory schemes. First, in order to compare with Russell and Ziegel's findings, we classified appointees as having "major" or "minor" connections with the party of appointment (and with opposition parties). Following Russell and Ziegel, an appointee had "minor" political connections if he or she made a financial contribution to a party, undertook minor constituency work for a party, or had social or professional connections with party leaders. An appointee who raised funds, sat on the executive of a party, was actively involved in an election or leadership campaign, or ran for office was considered to have "major" connections to a party.

Our second classification scheme was developed after we came to believe that the Russell and Ziegel coding did not capture adequately two important dimensions of the appointment process that we were alerted to by comments from web survey respondents and from respondents during interviews. One thing that the Russell and Ziegel scheme does not allow for is the possibility that an appointee was "non-political." As noted below, our respondents would sometimes stress that an appointee was non-political prior to their appointment. Our informants also made it clear that social or professional relationships with an influential member (or members) of the governing party could play a very key role in securing a judicial appointment. Based on this feedback we came to believe that close relationships with party officials were not "minor" connections as suggested by the Russell-Ziegel (RZ) schema. Our findings show that it is not the norm to have only high-profile connections with party officials without significant direct involvement with a party, but we believe that conceptually it is important to have a distinct category for these types of major "connections" (and more minor connections). Therefore, we developed the following classification scheme as described in Box 1 that we hope better highlights the importance of networking in judicial appointments. 


\section{Box 1}

Hausegger, Hennigar and Riddell (HHR) Scheme

\begin{tabular}{|c|c|}
\hline No Politics & $\begin{array}{l}\text { The appointee had no political activity or connections with } \\
\text { party officials prior to appointment. [Note: This is different } \\
\text { than "no known affiliation"; appointees were given this clas- } \\
\text { sification if respondents chose "no political" rather than } \\
\text { "unsure" regarding an appointee's background.] }\end{array}$ \\
\hline Minor Direct Involvement & $\begin{array}{l}\text { The informant was a probable donor to a federal political } \\
\text { party or was described as engaging in minor constituency } \\
\text { work for a party (federal or provincial). }\end{array}$ \\
\hline Major Connections & $\begin{array}{l}\text { The appointee had a close social relationship (spouse/partner, } \\
\text { immediate family ties, close friendships, former roommates) } \\
\text { or close professional relationship (law/business partner, cli- } \\
\text { ent, employee/employer) with a person who had major direct } \\
\text { involvement with a party (fundraiser, campaign manager, } \\
\text { executive member, cabinet minister and MP or senator). } \\
\text { [Note: We did not include former civil servants in this cat- } \\
\text { egory even though they likely had developed relationships } \\
\text { with government officials in the course of their work.] }\end{array}$ \\
\hline Major Direct Involvement & $\begin{array}{l}\text { The appointee engaged in fundraising, was an executive mem- } \\
\text { ber, was a senior campaign organizer in elections/leadership } \\
\text { contests, or ran for political office (provincial or federal). }\end{array}$ \\
\hline
\end{tabular}

\section{Findings}

\section{General Perceptions}

Table 1 presents the findings for our respondents' general assessment of the importance of political, social and professional connections for judicial appointments to the bench. An average rating was calculated for each province based on responses scaled from 1 to 5 , with 5 suggesting that the connection was "very important." The table demonstrates that in many provinces the perception exists that, despite changes to the federal selection process, politics still matters. Respondents from Prince Edward Island rated politics particularly strongly (4.83), followed closely by Newfoundland and Saskatchewan. British Columbia respondents felt political connections were least important (2.33), suggesting in interviews that $\mathrm{BC}$ was "less political" and that "people of all political stripes are getting through federally." However, in most other provinces respondents made comments (both on the survey and in interviews) suggesting that "politics plays a heavy role," and that the process was still "highly politicized." Some felt strongly enough to state that the system was "politically tainted," while others suggested that the screening committees themselves were "highly politicized," and that a "disturbingly large number 


\section{TABLE 1}

Assessment of the Importance of Connections by Respondents (mean rating from 1 "unimportant" to 5 "very important")

\begin{tabular}{lcccc}
\hline \hline & $\begin{array}{c}\text { Social and } \\
\text { Professional } \\
\text { Politics } \\
\text { (federal) }\end{array}$ & $\begin{array}{c}\text { Politics } \\
\text { (provincial) }\end{array}$ & $\begin{array}{c}\text { Social and } \\
\text { professional } \\
\text { (provincial) }\end{array}$ \\
\hline BC & 2.33 & 3.18 & 2.29 & 3.13 \\
AB & 4.00 & 4.13 & 3.93 & 3.86 \\
SK & 4.54 & 3.69 & 3.92 & 4.00 \\
MB & 4.47 & 4.00 & 3.79 & 3.92 \\
ON & 3.61 & 3.95 & 2.95 & 3.65 \\
QC & 4.00 & 3.71 & 3.00 & 3.43 \\
NB & 4.36 & 3.72 & 4.12 & 3.82 \\
NS & 3.94 & 3.80 & 3.80 & 3.71 \\
PE & 4.83 & 3.67 & 4.80 & 3.40 \\
NF & 4.67 & 4.33 & 2.33 & 3.33 \\
\hline
\end{tabular}

of federal appointments were based far more heavily on political connections than on merit." The ratings in Table 1 suggest that political connections play less of a role in provincial government appointments than at the federal level.

Table 1 also suggests that social and professional connections are important in all the provinces. Indeed, there is much less of a range of scores for these factors. While this measure does not provide the exact nature of this type of connection, it does suggest that the influences on judicial appointments may be quite complex. Direct political connections may matter but so too might belonging to particular law firms or travelling in the "right" circles. One respondent in Saskatchewan suggested there were three ways to get to the bench in that province: one could be active in the Liberal party when there is a Liberal government in Ottawa; one could be active in the Conservative party when there is a Conservative government in Ottawa; or one could be a member of the MacPherson, Leslie and Tyerman (MLT) law firm.

\section{Specific Findings, Replicating the RZ Model}

The anecdotal evidence discussed earlier in this article, and the general perceptions of our respondents, suggest that politics still matters in federal judicial appointments, despite the introduction of screening committees in 1989. In this step of our larger project we attempted to determine the accuracy of these perceptions by tracing actual connections between judges and the party that appointed them. Table 2 presents the results of that attempt using measures that mirror those used by Russell and Ziegel in their 1991 study. 
TABLE 2

Per Cent of Appointees Having Political Connections by Province (Using RZ Measures), 1989-2003

\begin{tabular}{|c|c|c|c|c|c|}
\hline & \multicolumn{2}{|c|}{$\begin{array}{c}\text { Party in } \\
\text { Power Involvement }\end{array}$} & \multirow[t]{2}{*}{$\begin{array}{l}\text { No Known } \\
\text { Affiliation }\end{array}$} & \multicolumn{2}{|c|}{$\begin{array}{l}\text { Opposition } \\
\text { Involvement }\end{array}$} \\
\hline & Major & Minor & & Major & Minor \\
\hline$\overline{\mathrm{BC}}$ & $\begin{array}{l}5.0 \% \\
(\mathrm{n}=6)\end{array}$ & $\begin{array}{c}9.1 \% \\
(\mathrm{n}=11)\end{array}$ & $\begin{array}{c}76.9 \% \\
(\mathrm{n}=93)\end{array}$ & $\begin{array}{c}2.5 \% \\
(\mathrm{n}=3)\end{array}$ & $\begin{array}{c}6.6 \% \\
(\mathrm{n}=8)\end{array}$ \\
\hline $\mathrm{AB}$ & $\begin{array}{c}20.5 \% \\
(\mathrm{n}=18)\end{array}$ & $\begin{array}{c}33.0 \% \\
(\mathrm{n}=29)\end{array}$ & $\begin{array}{c}37.5 \% \\
(\mathrm{n}=33)\end{array}$ & $\begin{array}{c}4.5 \% \\
(n=4)\end{array}$ & $\begin{array}{l}4.5 \% \\
(\mathrm{n}=4)\end{array}$ \\
\hline SK & $\begin{array}{l}44.7 \% \\
(\mathrm{n}=17)\end{array}$ & $\begin{array}{l}23.7 \% \\
(\mathrm{n}=9)\end{array}$ & $\begin{array}{l}28.9 \% \\
(\mathrm{n}=11)\end{array}$ & $\begin{array}{c}2.6 \% \\
(\mathrm{n}=1)\end{array}$ & $\begin{array}{c}0 \% \\
(\mathrm{n}=0)\end{array}$ \\
\hline MB & $\begin{array}{c}42.9 \% \\
(\mathrm{n}=18)\end{array}$ & $\begin{array}{c}26.2 \% \\
(\mathrm{n}=11)\end{array}$ & $\begin{array}{c}26.2 \% \\
(\mathrm{n}=11)\end{array}$ & $\begin{array}{c}2.4 \% \\
(\mathrm{n}=1)\end{array}$ & $\begin{array}{l}2.4 \% \\
(\mathrm{n}=1)\end{array}$ \\
\hline $\mathrm{ON}$ & $\begin{array}{c}9.5 \% \\
(\mathrm{n}=27)\end{array}$ & $\begin{array}{c}32.3 \% \\
(\mathrm{n}=92)\end{array}$ & $\begin{array}{c}55.4 \% \\
(\mathrm{n}=158)\end{array}$ & $\begin{array}{c}0.7 \% \\
(\mathrm{n}=2)\end{array}$ & $\begin{array}{l}2.1 \% \\
(\mathrm{n}=6)\end{array}$ \\
\hline QC & $\begin{array}{c}10.8 \% \\
(\mathrm{n}=18)\end{array}$ & $\begin{array}{c}13.2 \% \\
(\mathrm{n}=22)\end{array}$ & $\begin{array}{c}75.4 \% \\
(\mathrm{n}=126)\end{array}$ & $\begin{array}{c}0.6 \% \\
(\mathrm{n}=1)\end{array}$ & $\begin{array}{c}0 \% \\
(\mathrm{n}=0)\end{array}$ \\
\hline NB & $\begin{array}{c}60.0 \% \\
(\mathrm{n}=18)\end{array}$ & $\begin{array}{l}26.7 \% \\
(\mathrm{n}=8)\end{array}$ & $\begin{array}{l}10.0 \% \\
(\mathrm{n}=3)\end{array}$ & $\begin{array}{c}3.3 \% \\
(\mathrm{n}=1)\end{array}$ & $\begin{array}{c}0 \% \\
(\mathrm{n}=0)\end{array}$ \\
\hline NS & $\begin{array}{c}22.9 \% \\
(\mathrm{n}=11)\end{array}$ & $\begin{array}{c}29.2 \% \\
(\mathrm{n}=14)\end{array}$ & $\begin{array}{c}47.9 \% \\
(n=23)\end{array}$ & $\begin{array}{c}0 \% \\
(\mathrm{n}=0)\end{array}$ & $\begin{array}{c}0 \% \\
(\mathrm{n}=0)\end{array}$ \\
\hline $\mathrm{PE}$ & $\begin{array}{c}90 \% \\
(\mathrm{n}=9)\end{array}$ & $\begin{array}{c}0 \% \\
(\mathrm{n}=0)\end{array}$ & $\begin{array}{c}10 \% \\
(\mathrm{n}=1)\end{array}$ & $\begin{array}{c}0 \% \\
(\mathrm{n}=0)\end{array}$ & $\begin{array}{c}0 \% \\
(\mathrm{n}=0)\end{array}$ \\
\hline $\mathrm{NF}$ & $\begin{array}{l}18.5 \% \\
(\mathrm{n}=5)\end{array}$ & $\begin{array}{l}22.2 \% \\
(\mathrm{n}=6)\end{array}$ & $\begin{array}{c}44.4 \% \\
(\mathrm{n}=12)\end{array}$ & $\begin{array}{c}3.7 \% \\
(\mathrm{n}=1)\end{array}$ & $\begin{array}{l}11.1 \% \\
(\mathrm{n}=3)\end{array}$ \\
\hline Totals & $\begin{array}{c}17.2 \% \\
(\mathrm{n}=147)\end{array}$ & $\begin{array}{c}23.6 \% \\
(\mathrm{n}=202)\end{array}$ & $\begin{array}{c}55.0 \% \\
(\mathrm{n}=471)\end{array}$ & $\begin{array}{c}1.6 \% \\
(\mathrm{n}=14)\end{array}$ & $\begin{array}{c}2.6 \% \\
(\mathrm{n}=22)\end{array}$ \\
\hline
\end{tabular}

Comparing our results with the earlier study (see table A2 in the appendix) we find that, for all but two provinces (PEI and Quebec), the percentage of judges with major connections being appointed is lower after the introduction of the screening committees. In some provinces the difference is quite impressive. Nova Scotia, for example, went from 41.7 per cent with major political connections to only 22.9 per cent, and Newfoundland dropped from 33.3 per cent to 18.5 per cent. In total, we discovered that 17.2 per cent of judges appointed from 1989 to $2003 \mathrm{had}$ major connections to the party that appointed them, a number noticeably lower than the 24.2 per cent found by Russell and Ziegel for appointments made between 1984 and 1988. Interestingly, the appointments Prime Minister Mulroney made in his second term, after the introduction of the screening committees (1989 to 1993), demonstrate fewer major political connections than those he made before the committees (see table A3 in the appendix). These findings suggest the possibility that the screening 
committees may indeed have had some impact on the process, at least at this high level of connection.

For a few of the provinces (see, for example, Alberta) the percentage of minor connections is higher than that found by Russell and Ziegel (although our total minor connection score is very close: 23.6 per cent versus 23.3 per cent). ${ }^{10}$ In any case, adding major and minor connections together, Russell and Ziegel found that before the introduction of committees, 47.5 per cent of judicial appointees (excluding the territories) had some connection to the party that appointed them, while, using comparable measures, we find that 40.8 per cent had connections after the establishment of committees. Although this means that a considerable number of appointees continued to have connections with the party in power, the data also reflect the observation made by a number of our respondents who argued that the committee system has curtailed the appointment of some hard-core partisans who lacked the background to be recommended for appointment.

Overall, the pattern of political connections across provinces is relatively similar in each time period. In both studies, some Maritime provinces, Saskatchewan and Manitoba tend to have the highest level of major political connections and the lowest level of "no known affiliation." In our study, PEI demonstrates the highest level of major connections followed by New Brunswick, Saskatchewan and Manitoba, whereas in the Russell and Ziegel study Nova Scotia was in the top four and PEI was not. The general patterns we discover from 1989 to 2003 appear to be relatively constant across the Mulroney and Chrétien governments as well (see tables A3 and A4 in the appendix).

\section{Specific Findings using HHR Measures}

Table 3 presents results using our different measures of political connection. As mentioned above we not only made a distinction between major and minor connections, we also attempted to distinguish the type of those connections. Therefore, we have a category for major direct political activities (such as fundraising, running a candidate's campaign or being a member of the party executive), and a category for major social or professional connections (such as being the spouse, roommate or law partner of a major political player or even the minister of justice). While appointees falling in the first category definitely qualify as political, those falling in the latter category are not necessarily political themselves - and yet most observers would classify their appointment as a political one. By our measures, 22.4 per cent of appointees from 1989 to 2003 had backgrounds that suggested major political activities, major social or professional connections, or both. ${ }^{11}$ Of these, 5.3 per cent had only major social or professional connections. However, as reported in the last column of Table 3, 
TABLE 3

Province by Political Affiliation (HHR Measures) 1989-2003 (\% of appointees within province falling in each political affiliation)

\begin{tabular}{|c|c|c|c|c|c|}
\hline & No Politics & $\begin{array}{c}\text { Minor Direct } \\
\text { Activities }\end{array}$ & $\begin{array}{c}\text { Major } \\
\text { Connections } \\
\text { and/or Major } \\
\text { Direct } \\
\text { Activities }\end{array}$ & $\begin{array}{c}\text { Major } \\
\text { Connections } \\
\text { Only }\end{array}$ & $\begin{array}{c}\text { Major } \\
\text { Connections } \\
\text { with Minor } \\
\text { Direct } \\
\text { Activities }\end{array}$ \\
\hline $\begin{array}{l}\mathrm{BC} \\
(\mathrm{n}=121)\end{array}$ & $\begin{array}{c}16.5 \% \\
(\mathrm{n}=20)\end{array}$ & $\begin{array}{c}9.1 \% \\
(\mathrm{n}=11)\end{array}$ & $\begin{array}{c}5.8 \% \\
(\mathrm{n}=7)\end{array}$ & $\begin{array}{c}0.8 \% \\
(\mathrm{n}=1)\end{array}$ & $\begin{array}{c}0.8 \% \\
(\mathrm{n}=1)\end{array}$ \\
\hline $\begin{array}{l}\mathrm{AB} \\
(\mathrm{n}=88)\end{array}$ & $\begin{array}{l}10.2 \% \\
(\mathrm{n}=9)\end{array}$ & $\begin{array}{c}28.4 \% \\
(\mathrm{n}=25)\end{array}$ & $\begin{array}{c}26.1 \% \\
(n=23)\end{array}$ & $\begin{array}{c}5.7 \% \\
(\mathrm{n}=5)\end{array}$ & $\begin{array}{c}1.1 \% \\
(\mathrm{n}=1)\end{array}$ \\
\hline $\begin{array}{l}\text { SK } \\
(\mathrm{n}=38)\end{array}$ & $\begin{array}{l}13.2 \% \\
(\mathrm{n}=5)\end{array}$ & $\begin{array}{l}21.1 \% \\
(\mathrm{n}=8)\end{array}$ & $\begin{array}{c}55.3 \% \\
(\mathrm{n}=21)\end{array}$ & $\begin{array}{l}10.5 \% \\
(\mathrm{n}=4)\end{array}$ & $\begin{array}{l}7.9 \% \\
(\mathrm{n}=3)\end{array}$ \\
\hline $\begin{array}{l}\text { MB } \\
(\mathrm{n}=42)\end{array}$ & $\begin{array}{c}7.1 \% \\
(\mathrm{n}=3)\end{array}$ & $\begin{array}{l}19.0 \% \\
(\mathrm{n}=8)\end{array}$ & $\begin{array}{c}52.4 \% \\
(\mathrm{n}=22)\end{array}$ & $\begin{array}{c}9.5 \% \\
(\mathrm{n}=4)\end{array}$ & $\begin{array}{c}2.4 \% \\
(\mathrm{n}=1)\end{array}$ \\
\hline $\begin{array}{l}\mathrm{ON} \\
(\mathrm{n}=285)\end{array}$ & $\begin{array}{c}6.0 \% \\
(\mathrm{n}=17)\end{array}$ & $\begin{array}{c}29.8 \% \\
(\mathrm{n}=85)\end{array}$ & $\begin{array}{c}14.0 \% \\
(\mathrm{n}=40)\end{array}$ & $\begin{array}{c}4.6 \% \\
(n=13)\end{array}$ & $\begin{array}{c}2.1 \% \\
(\mathrm{n}=6)\end{array}$ \\
\hline $\begin{array}{l}\text { QC } \\
(\mathrm{n}=167)\end{array}$ & $\begin{array}{c}1.8 \% \\
(\mathrm{n}=3)\end{array}$ & $\begin{array}{c}12.0 \% \\
(\mathrm{n}=20)\end{array}$ & $\begin{array}{c}12.6 \% \\
(\mathrm{n}=21)\end{array}$ & $\begin{array}{c}1.8 \% \\
(\mathrm{n}=3)\end{array}$ & $\begin{array}{c}0.6 \% \\
(\mathrm{n}=1)\end{array}$ \\
\hline $\begin{array}{l}\text { NB } \\
(\mathrm{n}=30)\end{array}$ & $\begin{array}{c}3.3 \% \\
(\mathrm{n}=1)\end{array}$ & $\begin{array}{l}23.3 \% \\
(\mathrm{n}=7)\end{array}$ & $\begin{array}{c}76.7 \% \\
(n=23)\end{array}$ & $\begin{array}{l}16.7 \% \\
(\mathrm{n}=5)\end{array}$ & $\begin{array}{l}13.3 \% \\
(\mathrm{n}=4)\end{array}$ \\
\hline $\begin{array}{l}\mathrm{NS} \\
(\mathrm{n}=48)\end{array}$ & $\begin{array}{c}22.9 \% \\
(\mathrm{n}=11)\end{array}$ & $\begin{array}{c}20.8 \% \\
(\mathrm{n}=10)\end{array}$ & $\begin{array}{c}35.4 \% \\
(\mathrm{n}=17)\end{array}$ & $\begin{array}{l}12.5 \% \\
(\mathrm{n}=6)\end{array}$ & $\begin{array}{c}4.2 \% \\
(\mathrm{n}=2)\end{array}$ \\
\hline $\begin{array}{l}\mathrm{PE} \\
(\mathrm{n}=10)\end{array}$ & $\begin{array}{l}10.0 \% \\
(\mathrm{n}=1)\end{array}$ & $\begin{array}{c}0 \% \\
(\mathrm{n}=0)\end{array}$ & $\begin{array}{l}90.0 \% \\
(\mathrm{n}=9)\end{array}$ & $\begin{array}{c}0 \% \\
(\mathrm{n}=0)\end{array}$ & $\begin{array}{c}0 \% \\
(\mathrm{n}=0)\end{array}$ \\
\hline $\begin{array}{l}\mathrm{NF} \\
(\mathrm{n}=27)\end{array}$ & $\begin{array}{l}29.6 \% \\
(\mathrm{n}=8)\end{array}$ & $\begin{array}{l}11.1 \% \\
(\mathrm{n}=3)\end{array}$ & $\begin{array}{l}33.3 \% \\
(\mathrm{n}=9)\end{array}$ & $\begin{array}{l}14.8 \% \\
(\mathrm{n}=4)\end{array}$ & $\begin{array}{l}3.7 \% \\
(\mathrm{n}=1)\end{array}$ \\
\hline $\begin{array}{l}\text { Totals } \\
(\mathrm{n}=856)\end{array}$ & $\begin{array}{c}9.1 \% \\
(\mathrm{n}=78)\end{array}$ & $\begin{array}{c}20.7 \% \\
(\mathrm{n}=177)\end{array}$ & $\begin{array}{c}22.4 \% \\
(\mathrm{n}=192)\end{array}$ & $\begin{array}{c}5.3 \% \\
(\mathrm{n}=45)\end{array}$ & $\begin{array}{c}2.3 \% \\
(\mathrm{n}=20)\end{array}$ \\
\hline
\end{tabular}

when we examined those appointees more closely we discovered that several had some minor politics in their background (usually donating to a political party). In the end, only 2.3 per cent of judges appointed between 1989 and 2003 could arguably be classified as a major political appointment without being political themselves.

The number of judicial appointees with major and minor connections varied, of course, by province. Prince Edward Island had the lowest number of judges appointed (10) during our time period, but 90 per cent of those appointees had some major direct political activity in their background, the highest percentage of any province. New Brunswick was also very high with 76.7 per cent of its federal judicial appointments having some kind of major activity or connection in their background. New Brunswick differed from PEI, however, in that 16.7 per cent of its appointees had major social or professional connections without also hav- 
ing been involved in major political activity themselves (whereas PEI had none). Saskatchewan and Manitoba were the next highest provinces, each with over half of their appointees (55.3 per cent and 52.4 per cent respectively) having a history of major political activity, major social or professional connections or both. British Columbia is the province with the lowest number of appointees falling in the major political categories. Only 5.8 per cent of British Columbia appointees had these types of connections. Although we believe Table 3 allows for a more nuanced look at the type of connections between judges and the government appointing them, the overall provincial patterns mirror those using the Russell and Ziegel measures in terms of the provinces demonstrating the highest and lowest levels of major political associations.

The provincial patterns for minor direct political activities demonstrate some differences from those of the major ones. Ontario and Alberta have the highest levels of appointees with minor direct political activities in their background (perhaps reflecting the importance of political donations to the measure) while British Columbia and PEI have the lowest (PEI had little room for this type of connection with nine of its ten appointees having major political activities in their background).

More interesting, perhaps, is the "no politics" category. The numbers in this category are low as we only counted a judge as having no political background if it was definitively stated by respondents and not contradicted by any other respondent (we also did not put anyone in this category who provoked only an "unsure" from respondents). Despite our strict definition, Newfoundland had 29.6 per cent and Nova Scotia had 22.9 per cent of their appointees fall in this category. More surprisingly, 13.2 per cent of Saskatchewan judges appointed between 1989 and 2003 fell into this category. Thus, while Saskatchewan rates as the thirdhighest province in terms of major connections and political activities, it falls as the fourth-highest province in terms of appointees with "no politics" in their background. This may reflect the smaller size of the province (as with Nova Scotia and Newfoundland), which allows respondents to be more definitive in their answers. Thus we may be capturing the measure better in that province. Manitoba and New Brunswick present a more expected picture, scoring high in terms of major connections and low in terms of no politics.

Table 4 compares the findings of political affiliation for candidates put on the bench by Prime Minister Mulroney from 1989 to 1993 to those put on the bench by Prime Minister Chrétien from 1993 to 2003. There are not significant differences between the two prime ministers. However, our data suggests that Prime Minister Chrétien's appointees were slightly more likely to have major connections or major political activities in their background than those of Prime Minister Mulroney (at least in his second term). The two prime ministers were virtually 
TABLE 4

Appointing Prime Minister by Appointees Political Affiliation 1989-2003 (\% of PM's appointments in each political affiliation)

\begin{tabular}{lccccc}
\hline \hline & & $\begin{array}{c}\text { Major } \\
\text { Connections } \\
\text { and/or Major } \\
\text { Direct } \\
\text { Activities }\end{array}$ & $\begin{array}{c}\text { Major } \\
\text { Connections } \\
\text { Only }\end{array}$ & $\begin{array}{c}\text { Major } \\
\text { Connections } \\
\text { and Minor } \\
\text { Direct } \\
\text { Activities }\end{array}$ \\
\hline Mulroney & $9.2 \%$ & $17.5 \%$ & $21.8 \%$ & $5.0 \%$ & $1.7 \%$ \\
$(\mathrm{n}=303)$ & $(\mathrm{n}=28)$ & $(\mathrm{n}=53)$ & $(\mathrm{n}=66)$ & $(\mathrm{n}=15)$ & $(\mathrm{n}=5)$ \\
$\begin{array}{l}\text { Chrétien } \\
(\mathrm{n}=553)\end{array}$ & $9.0 \%$ & $22.4 \%$ & $22.8 \%$ & $5.4 \%$ & $2.7 \%$ \\
$(\mathrm{n}=50)$ & $(\mathrm{n}=124)$ & $(\mathrm{n}=126)$ & $(\mathrm{n}=30)$ & $(\mathrm{n}=15)$ \\
\hline
\end{tabular}

identical, however, in the proportion of appointees with no politics in their background.

Table 5 takes the next step and examines the quality of appointees chosen for the bench by the extent of their political affiliations (as mentioned above, respondents were asked to rate the appointees before they became judges). ${ }^{12}$ Those with major direct political activities, or major social or professional connections, in their past were rated "outstanding" by respondents only 8.3 per cent of the time, the lowest level of any category. This category also had a much higher number rated as only "poor" or "fair" than the other categories. The "no politics" category is perhaps the most instructive, however. While 32.1 per cent of these appointees were rated as "outstanding" (more than twice as many as any other category), none of these appointees was rated as "poor" or even "fair."

TABLE 5

Quality of Appointment by Political Affiliation HHR 1989-2003 (\% of each political affiliation falling within each rating category)

\begin{tabular}{lccccc}
\hline \hline & & $\begin{array}{c}\text { Major } \\
\text { Connections } \\
\text { and/or Major } \\
\text { Direct } \\
\text { Activities }\end{array}$ & $\begin{array}{c}\text { Major } \\
\text { Connections } \\
\text { Only }\end{array}$ & $\begin{array}{c}\text { Major } \\
\text { Connections } \\
\text { and Minor } \\
\text { Direct } \\
\text { Activities }\end{array}$ \\
\hline Outstanding & $32.1 \%$ & $15.8 \%$ & $8.3 \%$ & $13.3 \%$ & $10.0 \%$ \\
Very Good & $33.3 \%$ & $22.6 \%$ & $31.8 \%$ & $24.4 \%$ & $30.0 \%$ \\
Good & $14.1 \%$ & $12.4 \%$ & $28.1 \%$ & $28.9 \%$ & $30.0 \%$ \\
Fair & $0 \%$ & $1.7 \%$ & $12.0 \%$ & $6.7 \%$ & $10.0 \%$ \\
Poor & $0 \%$ & $0.6 \%$ & $4.2 \%$ & $2.2 \%$ & $0 \%$ \\
\hline
\end{tabular}




\section{Discussion}

\section{Perceptions versus Reality}

The perception exists in the media and among much of the legal community that politics plays a significant, if not predominant, role in federal judicial appointments. This perception is fueled by stories like that of a lawyer in Saskatchewan being appointed after representing the prime minister's son in a criminal matter or of a lawyer in the Maritimes being appointed as a "cushion" after her husband (a member of the provincial government) had an affair and their marriage ended in divorce. In nearly every province, many respondents suggested the appointment process was very political, involving much lobbying. A New Brunswick respondent suggested our asking about political connections was "like asking do you know if all Popes are Catholic." According to this respondent "there is generally only one criterion for s.96 judges: Does the party in power owe you?"

However, in undertaking this project, we wondered whether stories of obvious political patronage were reflective of the norm, or whether they were high profile outliers, colouring peoples' view and confusing the issue. Our findings suggest the answer to this may depend on the province. The respondents from PEI are probably in touch with the way their federal judicial appointments are done, as 90 per cent of its appointees in our time period did indeed have some kind of major political connection to the governing party. However, in provinces like Newfoundland, the perception seems to be out of step with the extent of political connections we actually discovered. Respondents from Newfoundland suggested political connections were very important — only respondents from PEI ranked their importance higher (see Table 1), and comments were made about how politics is "dominant" in judicial appointments in the province. However, despite these perceptions, Newfoundland placed in the bottom half of provinces in terms of the number of its appointees who had major political connections and, of all the provinces, Newfoundland has the highest number of appointees with "no politics" in their background. The distortion of perception versus reality was suggested by individual respondents in other provinces as well. For example, one respondent suggested that no judge was appointed solely on merit in their province, and argued that for a lawyer to become a judge they had to "work it." And yet, when asked about each individual appointed to the bench from 1989 to 2003, this same respondent consistently rated a large number of appointees as having "no politics" in their background. A thorough examination of each individual judge highlights the importance of carefully measuring the factors influencing judicial appointments and sug- 
gests that the need to be politically active in order to secure an appointment may be exaggerated in some contexts.

Obviously, however, our data suggest a reality in which differences persist between provinces in the importance of the political backgrounds of those appointed to the bench. Despite the introduction of committees, New Brunswick, for example, still has a large number of appointees with major political connections (often through direct participation), as does Saskatchewan and Manitoba. The appointees in British Columbia, by contrast, demonstrate very few political connections - a low number that has become even smaller since the introduction of the committees. It may be that the small size of provinces such as New Brunswick and Saskatchewan offers more potential for political connections to flourish and to influence appointments.

However, depending on the province, there may be a need for even those who are not directly active in politics to be championed (or at least not vetoed) by those who are connected to influential individuals in the governing party, or by "gate keepers." Gate keepers were identified by a number of respondents and included individuals and law firms (such as Stewart McKelvey in the Maritimes) that seem to have significant influence in the appointment process. Respondents identified many avenues by which this political networking and lobbying takes place, though the importance of the regional minister was highlighted by respondents across the country. A story of one appointee in Alberta detailed that when the regional minister (Harvey Andre) blocked an appointment (believing the appointee was a supporter of the opposition party), the appointee appealed to an influential political friend. This friend had Progressive Conservative staffers go through membership lists until they found an old membership card of the appointee. This was then sent to the minister who promptly removed his objection, allowing the appointment to go through. We attempted to capture these kinds of connections in our "major connections" measure. As noted in the findings section of the article, a significant number of appointees demonstrated these major social and professional connections in each province, and 2.3 per cent displayed only this type of connection. Having indirect contact to regional ministers is a significant-and we believe major-connection, and one that needs to be considered in our models of influences on appointments. While we did encourage respondents to tell us about such networking activity, we recognize that it is more difficult to capture such "behind-the-scenes" influence so we could be underestimating somewhat how influential this process is. It is worth noting that even in provinces that do not display heavy major - or even minor - connections (see for example, Nova Scotia), very few candidates affiliated with opposition parties are placed on the bench, which may be an indicator of the influence that "networks" play in many provinces. 


\section{Group Representation}

For judges appointed from 1989 to 2003, another consideration appears to have come to the forefront: group representation. Several respondents mentioned the importance of gender, ethnicity and language to the process, suggesting it was another "card that could be played" and one that could even "trump politics." The Liberal government, in particular, appears to have actively sought out aboriginal lawyers in an effort to encourage them to apply for judicial vacancies. And our data suggest that both the Mulroney and Chrétien governments made conscious efforts to increase the number of women on the federal bench (Riddell et al., 2008).

Reaction to group representation was mixed, with some respondents suggesting they felt such appointees were of lower quality. This statement was usually directed at female appointees who, in our time period, tended to be appointed at a younger age than their male colleagues. However, when we examined the numbers for gender, female appointees were not rated significantly lower than males. Indeed, a slightly higher number of females were in both the "outstanding" and the "very good" categories of our quality measure. When we examined the screening committee results for males and females we also discovered little difference between the genders. When rated as "highly recommended" or "recommended" versus "unable to recommend" roughly the same percentage of females as males achieved the highest two categories. From 2006 to 2007 (the latest figures available) a slightly higher percentage of women fell into the top two categories.

Interestingly, female appointees were slightly less likely to have major direct political activities in their background, but were slightly more likely to have major social or professional connections to the government appointing them.

\section{Elevations and Promotions}

Given the leadership role that appellate court judges and chief judges (and their associate chiefs) play in shaping the law and administering the courts, we examined the connections of those individuals in our dataset who subsequently received an administrative promotion (to associate chief or chief justice) or elevation to an appellate court up to July 2008. Interestingly, we found that this subset of appointees had a higher percentage of individuals with "no politics" compared to our overall sample, but also had a higher percentage of individuals with major direct activities or major connections. For instance, 28.2 per cent of judges who were elevated and 45.2 per cent of judges who were given administrative promotions had major direct activities or major connections, compared to 22.4 per cent in our overall dataset. The numbers were fairly consistent between Conservative governments (Mulroney 1988-1993 and Harper 2006-2008) and Lib- 
eral governments (Chrétien 1993-2003 and Martin 2004-2005). The numbers also tended to reflect the general provincial patterns discussed above, though one notable exception was Ontario, which featured a noticeably higher percentage of partisans being provided elevations and administrative appointments compared to "regular" appointments. ${ }^{13}$

Given the relatively low numbers in this subset (78 elevations and 31 administrative promotions), we are hesitant to read too much into the results. Perhaps this pattern signals that for the arguably more important appointments, which are not screened by the committees, governments are striving to choose individuals that they think they can "trust" in these influential positions: those without political backgrounds or those who have had considerable experience with the party in power. The potential that politics might influence elevations and promotions was described as “disturbing” by Russell and Ziegel (1991: 22), who found that 43.3 per cent of the elevations and promotions made by the Mulroney government between 1984 and 1988 had major (22.4 per cent) or minor (20.9 per cent) connections to the Conservative government.

\section{Implications}

Although the 1990s did see some egregious appointments, and reports from a few provinces suggested there were instances where committees were asked to re-evaluate individuals by the political powers of the day, in general, the vast majority of respondents agreed that the new committee system screened out poor candidates. As one of our respondents stated, "No matter how good your political connections, if you are a crappy lawyer you will not get on the bench." Several respondents suggested that the "real political animals" were now being shut out of the process. One respondent told us that a former political party leader was incredulous that, under the committee system, a well-connected party supporter was not going to be put on the bench. Indeed, some respondents, including several former senior government officials, suggested that the introduction of the committee system might be most beneficial to the minister of justice who, when faced with those lobbying him to put their campaign managers on the bench, could simply state, "There is nothing I can do, he did not make it through the committee." Our replication of the Russell and Ziegel model suggests that the appointment of judges with major political connections is indeed down, and the difference between Prime Minister Mulroney's first and second terms (before and after the introduction of the committees) is particularly suggestive. Given that Russell and Ziegel's data and our own suggest that the appointments of those with strong political connections tended to be rated lower on average than those without major connections, the introduction of the screening committees may have generated at least incremental improvements to the quality of the s.96 and lower s.101 
bench. However, our numbers also suggest that partisanship still plays an important role in the process, especially in some provinces, and that this can influence both the perception of the judiciary and its actual functioning if the best candidates are possibly being overlooked because of political considerations. Of course, our data only explicitly measure perceptions of the quality of the appointment to the bench. The next step is to systematically measure the quality of those appointments once they are on the bench, whether they turn out to be good judges. The patterns we have discovered for federal judicial appointments will be a cause for concern if those who are politically connected do in fact make poorer judges. ${ }^{14}$

\section{Broader Implications and Possible Reform}

The appointment process is important to those involved in the process and to those who may come before the courts. However, it also has the potential for larger implications on judicial independence and accountability. Law makers have also become increasingly concerned with the process as the power of the courts has become more apparent in recent decades. With cynicism growing in various corners about the role of patronage in the current process there have been calls for change. One possibility is something along the lines of some provincial appointment schemes that feature nominating committees that send up a limited list of names from which the attorney general or minister of justice is expected to choose. This is the kind of judicial appointment system recommended by the Canadian Bar Association (2005) and one that Britain has recently introduced (Malleson, 2006). This differs from the current federal "screening" system which only allows the committees to rate the candidates rather than narrowing down the choices for the minister of justice. Provincial "nominating" systems, such as the one in Ontario, theoretically should allow for less partisan maneuvering by the appointing politician as the choice boundaries are limited. However, the current Harper government has opted to make changes to the federal screening committees rather than move to a nominating committee system. ${ }^{15}$

Another possibility would be to increase the involvement of judicial councils in judicial selection. This is favoured in some civil law countries, such as France, particularly for promotions. However, some of our respondents warned against a system that would give judges (or lawyers' associations) even more influence in how future judges are chosen, given their already considerable influence. A large number of our respondents also argued against more direct input by legislators or voters as featured in many selection systems in the US. Concerns were expressed that legislative confirmation processes (as happens for federal US judges) and elections (many US states feature direct election of judges or retention elections following the initial appointment) politicize the judiciary and 
undermine judicial independence. Interestingly, however, a recent Canadian poll found that a majority of respondents favoured the election of judges (Makin, 2007). ${ }^{16}$ It is possible that this partly reflects the public's view that the current system lacks sufficient integrity.

Although it is unlikely that Canadians will ever elect judges, comparative research suggests that eliminating "politics" from the judicial selection process may not always be possible or even viewed as desirable. Judicial organizations in Latin countries, for example, have been known to develop along political lines and then vie for influence on judicial councils, which play a significant role in the appointment process (Guarnieri, 2004). Studies of "merit based" selection systems in the US states (which bear some similarities to provincial nominating systems in Canada) have found that commissioners on screening or nominating committees tend to be more politically active than the general population, that partisanship affected the selection of both lawyer and lay commissioners, that bar politics influenced the process and that partisan considerations often entered into the deliberations of merit committees (especially those that were not required to be bipartisan) (Reddick, 2002). Proponents of current US judicial selection systems argue, however, that because courts make important public decisions, including ones that influence policy, it is necessary to have some democratic channels for input into how judges are selected and accountability mechanisms that are closely linked to the people through judicial retention elections (see Tarr, 2006: ch. 3). ${ }^{17}$

In Ontario, the government of Premier Mike Harris showed that when there is political concern over judicial decision-making - in this case over perceptions that provincial judges were too lenient in sentencing in criminal cases - then even a seemingly non-political nominating system of appointments can become politicized. One study found that the Harris government, known to request new or expanded lists of candidates from the nominating committee, appointed a sizeable number of individuals (nearly 30 per cent of appointees between 1998-2003) who were Conservative donors (Matisz, 2005; see also Copeland, 1997). ${ }^{18}$ Concomitant with this trend in judicial appointments, members of Harris' caucus introduced private members bills to make the judiciary more directly accountable to the legislature for their decisions, particularly in sentencing. Although these bills were not passed, their introduction (and subsequent lack of success) highlights how questions of judicial selection, independence, accountability and decision-making are interrelated.

\section{Conclusions}

We argue that the discussion above illustrates the need to carefully examine any reform recommendation. Conceptions of judicial independence 
and legitimacy, and the impact of different appointment systems on them need to be thoroughly studied. Discussions about judicial appointment processes also need to consider how much emphasis should be placed on diversity and what kind of diversity; whether different appointment criteria and processes should be developed for different kinds of courts; whether judges appointed under different kinds of appointment systems decide cases differently; and how much political activity should be considered evidence of meritorious community involvement - or considered evidence of jockeying for a judicial position. This research provides some much needed empirical data that can begin to form a foundation for such discussions in the context of federal judicial appointments. However, we argue more research needs to be done before the implications of the different choices can be fully understood.

\section{Notes}

1 These years were chosen to provide a comparison between the 1984-1988 Mulroney appointments and the 1989-1993 Mulroney appointments and to compare the Mulroney appointments with the Chrétien appointments (1993-2003). The time period is long enough and has an adequate number of appointees to make a reasonable assessment of the new appointment process. The dataset also provides a comparison point for future research on whether recent changes made to the appointment process by the Harper government result in different patterns than the ones we found.

2 There were a total of 228 appointments made to the s.96 courts, the Federal Court (trial and appeal division), the Tax Court and the Supreme Court. Elevations were counted in these data as were administrative promotions to associate chief justice or chief justice.

3 Committee assessments were valid for three years until 1999, when it was reduced to two years.

4 In 1994, the total number of lay people appointed to the committees was expanded from one to three. Also, in 1994, the single committee for Ontario was replaced by three regional committees (East and North Ontario, West and South Ontario, and Metro Toronto) and the single Quebec committee was replaced by two committees (one for Quebec West and one for Quebec East, which reflects the judicial district system in Quebec). Membership on a committee is a three-year term (raised from just two years in 1999) renewable for a single additional term (see Millar, 2000: 616.).

5 Cumulative figures supplied by the Office of the Commissioner for Federal Judicial Affairs show that the pattern of having nearly 40 per cent of candidates ranked as "recommended" or "highly recommended" has continued up to the present (May 2006).

6 To be counted as a probable donor, all three parts of the judge's name had to be represented (first, last and middle initial) or the name had to be uncommon. To be counted as an uncommon name, and thus a probable donor, the judge's name could not appear in a nationwide "find a person" search engine (www.canada411.ca) more than twice. This included either the judge's complete first and last name or the judge's first initial and last name. Therefore if John Sproat appeared only once in the search engine but J. Sproat was listed 18 times, the name was not considered uncommon enough for us to be confident this donor was the judge of interest. 
7 Some individuals received more than one appointment during our time frame. For the purposes of this study, we are primarily interested in an individual's first appointment within the 1989 to 2003 time frame, which in some cases was an elevation from a lower court or an administrative promotion (to associate chief justice or chief justice). For example, if "Joe Smith" was appointed to the trial court in 1992 and was then elevated to the Court of Appeal in 2001, for this project we are only interested in the 1992 appointment. It would be coded as an appointment by the Mulroney government to the s.96 trial court.

8 Individuals appointed to the Federal Court or Tax Court were included in the list of appointees from the province in which they worked prior to their appointment.

9 For the sake of potential comparisons with provincial appointment systems, these questions were repeated with reference to s.92 appointments.

10 We are reluctant to read too much into this result as we believe some of the higher results may be attributable to our earlier study of political donations (a component of the minor connections measure), which uncovered probable donations from government records, rather than relying on reporting by respondents. Our measure should thus capture more political donations, and flag a higher number of minor connections as a result.

11 This number comes closer to the Russell and Ziegel score for major connections (24.2 per cent), but includes the social and professional connections that they regarded as only minor connections.

12 We also divided the data to examine the quality of appointees by their appointing prime minister. The differences between Prime Ministers Mulroney and Chrétien were not significant.

13 Some of the judges included in our sample had sat on previous courts before; thus their first appointment in our time frame was an elevation (from a s.92 or s.96 court) or a promotion. We ran our model excluding those individuals whose first appointment in our dataset was an elevation or promotion to analyze the results for only "regular" appointments. We found that including only the non-elevated or nonpromoted appointments did not change the overall results in any significant way; hence we are able to compare those individuals who were subsequently elevated or promoted to our overall numbers.

14 While many assume that this will, in fact, be the case when appointing politically connected people perceived to be less qualified than other potential candidates, it is a separate empirical question that needs to be explicitly studied. It may be that someone who was thought to be a very good quality appointment turns out not to have the temperament necessary to control their courtroom, move a trial along efficiently or be able to make a decision in a timely manner. And those who were thought to be only fair quality when appointed may thrive once on the bench. We heard some anecdotal evidence from our respondents that this does happen on occasion.

15 As noted above, the Harper government returned to a ranking system of "recommended" or "not recommended." The Harper government also made the judicial appointee a non-voting chair and added a police representative to the committee. For an analysis of the implications of these changes, see Riddell et al. (2009).

16 In the 1990s, however, a two-thirds majority of respondents favoured judicial selection through a non-partisan committee. See Greene et al. (1998: 39) reporting the results obtained by Maureen Mancuso and her colleagues in A Question of Ethics (1998).

17 Tarr notes that there are many critics of US appointment systems and of having retention elections as a method of accountability. Uncompetitive elections, uninformed electorates and the need for fund-raising are cited as potential problems with retention elections.

18 The percentage of donors to the appointing party was significantly higher than in previous years. Matisz found that when the Liberals took power in Ontario under 
Premier Dalton McGuinty, the number of lay people on the nominating committee who were Liberal donors went up but that this did not translate into Liberal donors being appointed to the provincial bench at least up until 2005, the final year for which data was collected. A member of the Ontario Judicial Advisory Committee, Paul Copeland (1997), complained about the propensity of the Harris government to request more names from the nominating committee. He stated that "It's my concern that the actions of the Attorney General in regard to rejecting the list of seven remaining people is in effect to render the working of this committee almost meaningless."

\section{References}

Canadian Bar Association (CBA). 1985. The Appointment of Judges in Canada. Toronto: CBA [McKelvey Report].

Canadian Bar Association (CBA). 2005. "Federal Judicial Appointment Process." www.cba.org/CBA/submissions/pdf/05-43-eng.pdf (July 2009).

Commissioner for Federal Judicial Affairs, Office. http://www.fja-cmf.gc.ca (July 2009).

Copeland, Paul. 1997. "Judicial Appointment Advisory Committee Information Report." In Criminal Law Association Newsletter, April, http://www.criminallawyers.ca/ newslett/apr97/copeland.htm (July 2009).

Forcese, Craig and Aaron Freeman. 2005. The Laws of Government: The Legal Foundations of Canadian Government. Toronto: Irwin Law.

Greene, Ian, Carl Baar, Peter McCormick, George Szablowski and Martin Thomas. 1998. Final Appeal: A Study of Appellate Court Decision-Making. Toronto: Lorimer.

Guarnieri, Carlo. 2004. "Appointment and career of judges in continental Europe: the rise of judicial self-government." Legal Studies 24: 169-87.

Makin, Kirk. 2005. "Appointment of Judges Too Political, Critics Say." The Globe and Mail (Toronto), May 16, A7.

Makin, Kirk. 2007. "Two-thirds Back Electing Judges.” The Globe and Mail (Toronto), April. 9, A1.

Malleson, Kate. 2006. "The New Judicial Appointments Commission in England and Wales: New Wine in New Bottles?" In Appointing Judges in an Age of Judicial Power: Critical Perspectives from Around the World, ed. Kate Malleson and Peter H. Russell. Toronto: University of Toronto Press.

Mancuso, Maureen, Michael M. Atkinson, André Blais, Ian Greene and Neil Nevitte. 1998. A Question of Ethics: Canadians Speak Out. Toronto: Oxford University Press.

Matisz, Derek. 2005. "Appointment of s.92 Judges in Canada." Unpublished MA major research paper. University of Guelph, Guelph, Ontario.

Meek, Jim. 1998. "Justice Heather Robertson: 'Not Recommended.'” Halifax ChronicleHerald, July 14. B1.

Millar, Andre S. 2000. "The 'New' Federal Judicial Appointments Process: the First Ten Years." Alberta Law Review 38: 616-53.

Reddick, Malia. 2002. "Merit Selection: A Review of the Social Scientific Literature." Dickinson Law Review 106: 729-45.

Riddell, Troy, Lori Hausegger and Matthew Hennigar. 2008. "Federal Judicial Appointments: A Look at Patronage in Federal Appointments since 1988." University of Toronto Law Journal 58 (1): 39-74.

Riddell, Troy, Lori Hausegger and Matthew Hennigar. 2009. "Federal Judicial Selection: Examining the Harper Appointments and Reforms." Journal of Parliamentary and Political Law 2: 499-522.

Russell, Peter and Jacob Ziegel. 1991. "Federal Judicial Appointments: An Appraisal of the First Mulroney Government's Appointments and the New Judicial Advisory Committees." University of Toronto Law Journal 41(1): 4-37. 
Schmitz, Cristin. 2005. "Federal Judges Often Liberal Donors, Survey Finds." Ottawa Citizen, May 6, A5.

Tarr, G. Alan. 2006. Judicial Process and Judicial Policymaking. $4^{\text {th }}$ ed. Belmont CA: Thomson.

\section{Appendix}

\section{TABLE A1}

\section{Number of Appointees}

\begin{tabular}{lccc}
\hline \hline & Total & $\begin{array}{c}\text { Mulroney } \\
(1989-1993)\end{array}$ & $\begin{array}{c}\text { Chrétien } \\
(1993-2003)\end{array}$ \\
\hline BC & 121 & 50 & 71 \\
AB & 88 & 26 & 62 \\
SK & 38 & 8 & 30 \\
MB & 42 & 18 & 24 \\
ON & 285 & 107 & 178 \\
QB & 167 & 56 & 111 \\
NB & 30 & 8 & 22 \\
NS & 48 & 18 & 30 \\
PE & 10 & 3 & 7 \\
NFLD & 27 & 9 & 18 \\
Totals & 856 & 303 & 553 \\
\hline
\end{tabular}

Note: If an appointee was given a subsequent appointment (say, to chief justice or from the s.96 court to the s.96 appeal court) only the first appointment from 1989 to 2003 was analyzed.

TABLE A2

Mulroney Appointments 1984-1988 (Russell and Ziegel data)*

\begin{tabular}{|c|c|c|c|c|c|}
\hline & \multicolumn{2}{|c|}{$\begin{array}{l}\text { Party in } \\
\text { Power Involvement }\end{array}$} & \multirow[t]{2}{*}{$\begin{array}{l}\text { No Known } \\
\text { Affiliation }\end{array}$} & \multicolumn{2}{|c|}{$\begin{array}{l}\text { Opposition } \\
\text { Involvement }\end{array}$} \\
\hline & Major & Minor & & Major & Minor \\
\hline $\mathrm{BC}$ & $\begin{array}{c}12.5 \% \\
(\mathrm{n}=5)\end{array}$ & $\begin{array}{c}17.5 \% \\
(n=7)\end{array}$ & $\begin{array}{c}52.5 \% \\
(\mathrm{n}=21)\end{array}$ & $\begin{array}{c}17.5 \% \\
(\mathrm{n}=7)\end{array}$ & $\begin{array}{c}0 \% \\
(\mathrm{n}=0)\end{array}$ \\
\hline $\mathrm{AB}$ & $\begin{array}{l}22.7 \% \\
(\mathrm{n}=5)\end{array}$ & $\begin{array}{l}13.6 \% \\
(n=3)\end{array}$ & $\begin{array}{c}54.5 \% \\
(\mathrm{n}=12)\end{array}$ & $\begin{array}{c}4.5 \% \\
(n=1)\end{array}$ & $\begin{array}{l}4.5 \% \\
(n=1)\end{array}$ \\
\hline SK & $\begin{array}{l}50.0 \% \\
(\mathrm{n}=5)\end{array}$ & $\begin{array}{l}30.0 \% \\
(\mathrm{n}=3)\end{array}$ & $\begin{array}{l}10.0 \% \\
(\mathrm{n}=1)\end{array}$ & $\begin{array}{c}0 \% \\
(\mathrm{n}=0)\end{array}$ & $\begin{array}{l}10.0 \% \\
(\mathrm{n}=1)\end{array}$ \\
\hline MB & $\begin{array}{l}50.0 \% \\
(n=4)\end{array}$ & $\begin{array}{l}37.5 \% \\
(n=3)\end{array}$ & $\begin{array}{l}12.5 \% \\
(\mathrm{n}=1)\end{array}$ & $\begin{array}{c}0 \% \\
(\mathrm{n}=0)\end{array}$ & $\begin{array}{c}0 \% \\
(\mathrm{n}=0)\end{array}$ \\
\hline ON & $\begin{array}{c}19.0 \% \\
(\mathrm{n}=11)\end{array}$ & $\begin{array}{c}25.9 \% \\
(\mathrm{n}=15)\end{array}$ & $\begin{array}{c}53.4 \% \\
(\mathrm{n}=31)\end{array}$ & $\begin{array}{c}0 \% \\
(\mathrm{n}=0)\end{array}$ & $\begin{array}{c}1.7 \% \\
(\mathrm{n}=1)\end{array}$ \\
\hline QC & $\begin{array}{c}6.8 \% \\
(n=3)\end{array}$ & $\begin{array}{c}29.5 \% \\
(\mathrm{n}=13)\end{array}$ & $\begin{array}{c}56.8 \% \\
(n=25)\end{array}$ & $\begin{array}{c}6.8 \% \\
(\mathrm{n}=3)\end{array}$ & $\begin{array}{c}0 \% \\
(\mathrm{n}=0)\end{array}$ \\
\hline NB & $\begin{array}{c}78.6 \% \\
(n=11)\end{array}$ & $\begin{array}{c}0 \% \\
(\mathrm{n}=0)\end{array}$ & $\begin{array}{l}21.4 \% \\
(n=3)\end{array}$ & $\begin{array}{c}0 \% \\
(\mathrm{n}=0)\end{array}$ & $\begin{array}{c}0 \% \\
(\mathrm{n}=0)\end{array}$ \\
\hline
\end{tabular}


TABLE A2 (Continued)

\begin{tabular}{|c|c|c|c|c|c|}
\hline & \multicolumn{2}{|c|}{$\begin{array}{c}\text { Party in } \\
\text { Power Involvement }\end{array}$} & \multirow[t]{2}{*}{$\begin{array}{l}\text { No Known } \\
\text { Affiliation }\end{array}$} & \multicolumn{2}{|c|}{$\begin{array}{l}\text { Opposition } \\
\text { Involvement }\end{array}$} \\
\hline & Major & Minor & & Major & Minor \\
\hline NS & $\begin{array}{l}41.7 \% \\
(n=5)\end{array}$ & $\begin{array}{l}33.3 \% \\
(\mathrm{n}=4)\end{array}$ & $\begin{array}{l}16.7 \% \\
(\mathrm{n}=2)\end{array}$ & $\begin{array}{c}8.3 \% \\
(\mathrm{n}=1)\end{array}$ & $\begin{array}{c}0 \% \\
(\mathrm{n}=0)\end{array}$ \\
\hline PE & $\begin{array}{l}28.6 \% \\
(n=2)\end{array}$ & $\begin{array}{l}42.9 \% \\
(n=3)\end{array}$ & $\begin{array}{l}14.3 \% \\
(\mathrm{n}=1)\end{array}$ & $\begin{array}{c}0 \% \\
(\mathrm{n}=0)\end{array}$ & $\begin{array}{l}14.3 \% \\
(\mathrm{n}=1)\end{array}$ \\
\hline NF & $\begin{array}{l}33.3 \% \\
(n=4)\end{array}$ & $\begin{array}{c}16.7 \% \\
(\mathrm{n}=2)\end{array}$ & $\begin{array}{l}50.0 \% \\
(\mathrm{n}=6)\end{array}$ & $\begin{array}{c}0 \% \\
(\mathrm{n}=0)\end{array}$ & $\begin{array}{c}0 \% \\
(\mathrm{n}=0)\end{array}$ \\
\hline Totals & $\begin{array}{c}24.2 \% \\
(\mathrm{n}=55)\end{array}$ & $\begin{array}{c}23.3 \% \\
(\mathrm{n}=53)\end{array}$ & $\begin{array}{c}45.4 \% \\
(n=103)\end{array}$ & $\begin{array}{c}5.3 \% \\
(n=12)\end{array}$ & $\begin{array}{l}1.8 \% \\
(n=4)\end{array}$ \\
\hline
\end{tabular}

*Total scores differ slightly from Russell and Ziegel's published totals as the one NWT judge has been removed from this table (1991, table 11).

TABLE A3

Mulroney Appointments 1989-1993 (RZ Model)

\begin{tabular}{|c|c|c|c|c|c|}
\hline & \multicolumn{2}{|c|}{$\begin{array}{c}\text { Party in } \\
\text { Power Involvement }\end{array}$} & \multirow[t]{2}{*}{$\begin{array}{l}\text { No Known } \\
\text { Affiliation }\end{array}$} & \multicolumn{2}{|c|}{$\begin{array}{l}\text { Opposition } \\
\text { Involvement }\end{array}$} \\
\hline & Major & Minor & & Major & Minor \\
\hline $\begin{array}{l}\mathrm{BC} \\
(\mathrm{n}=50)\end{array}$ & $\begin{array}{c}4.0 \% \\
(n=2)\end{array}$ & $\begin{array}{l}12.0 \% \\
(\mathrm{n}=6)\end{array}$ & $\begin{array}{c}70.0 \% \\
(\mathrm{n}=35)\end{array}$ & $\begin{array}{c}4.0 \% \\
(n=2)\end{array}$ & $\begin{array}{l}10.0 \% \\
(\mathrm{n}=5)\end{array}$ \\
\hline $\begin{array}{l}A B \\
(n=26)\end{array}$ & $\begin{array}{l}23.1 \% \\
(n=6)\end{array}$ & $\begin{array}{l}34.6 \% \\
(\mathrm{n}=9)\end{array}$ & $\begin{array}{l}34.6 \% \\
(\mathrm{n}=9)\end{array}$ & $\begin{array}{c}3.8 \% \\
(\mathrm{n}=1)\end{array}$ & $\begin{array}{c}3.8 \% \\
(\mathrm{n}=1)\end{array}$ \\
\hline $\begin{array}{l}\text { SK } \\
(n=8)\end{array}$ & $\begin{array}{l}62.5 \% \\
(\mathrm{n}=5)\end{array}$ & $\begin{array}{c}0 \% \\
(\mathrm{n}=0)\end{array}$ & $\begin{array}{l}37.5 \% \\
(\mathrm{n}=3)\end{array}$ & $\begin{array}{c}0 \% \\
(\mathrm{n}=0)\end{array}$ & $\begin{array}{c}0 \% \\
(\mathrm{n}=0)\end{array}$ \\
\hline $\begin{array}{l}\mathrm{MB} \\
(\mathrm{n}=18)\end{array}$ & $\begin{array}{l}44.4 \% \\
(n=8)\end{array}$ & $\begin{array}{l}27.8 \% \\
(n=5)\end{array}$ & $\begin{array}{l}16.7 \% \\
(n=3)\end{array}$ & $\begin{array}{c}5.6 \% \\
(\mathrm{n}=1)\end{array}$ & $\begin{array}{c}5.6 \% \\
(\mathrm{n}=1)\end{array}$ \\
\hline $\begin{array}{l}\text { ON } \\
(\mathrm{n}=107)\end{array}$ & $\begin{array}{c}10.3 \% \\
(\mathrm{n}=11)\end{array}$ & $\begin{array}{c}25.2 \% \\
(\mathrm{n}=27)\end{array}$ & $\begin{array}{c}59.8 \% \\
(n=64)\end{array}$ & $\begin{array}{c}1.9 \% \\
(\mathrm{n}=2)\end{array}$ & $\begin{array}{c}2.8 \% \\
(\mathrm{n}=3)\end{array}$ \\
\hline $\begin{array}{l}\text { QC } \\
(\mathrm{n}=56)\end{array}$ & $\begin{array}{l}10.7 \% \\
(n=6)\end{array}$ & $\begin{array}{l}16.1 \% \\
(\mathrm{n}=9)\end{array}$ & $\begin{array}{c}71.4 \% \\
(\mathrm{n}=40)\end{array}$ & $\begin{array}{c}1.8 \% \\
(\mathrm{n}=1)\end{array}$ & $\begin{array}{c}0 \% \\
(\mathrm{n}=0)\end{array}$ \\
\hline $\begin{array}{l}\text { NB } \\
(\mathrm{n}=8)\end{array}$ & $\begin{array}{c}50.0 \% \\
(\mathrm{n}=4)\end{array}$ & $\begin{array}{l}25.0 \% \\
(\mathrm{n}=2)\end{array}$ & $\begin{array}{l}12.5 \% \\
(\mathrm{n}=1)\end{array}$ & $\begin{array}{l}12.5 \% \\
(\mathrm{n}=1)\end{array}$ & $\begin{array}{c}0 \% \\
(\mathrm{n}=0)\end{array}$ \\
\hline $\begin{array}{l}\text { NS } \\
(n=18)\end{array}$ & $\begin{array}{l}38.9 \% \\
(\mathrm{n}=7)\end{array}$ & $\begin{array}{l}22.2 \% \\
(\mathrm{n}=4)\end{array}$ & $\begin{array}{l}38.9 \% \\
(\mathrm{n}=7)\end{array}$ & $\begin{array}{c}0 \% \\
(\mathrm{n}=0)\end{array}$ & $\begin{array}{c}0 \% \\
(\mathrm{n}=0)\end{array}$ \\
\hline $\begin{array}{l}P E \\
(n=3)\end{array}$ & $\begin{array}{l}66.7 \% \\
(n=2)\end{array}$ & $\begin{array}{c}0 \% \\
(\mathrm{n}=0)\end{array}$ & $\begin{array}{l}33.3 \% \\
(n=1)\end{array}$ & $\begin{array}{c}0 \% \\
(\mathrm{n}=0)\end{array}$ & $\begin{array}{c}0 \% \\
(\mathrm{n}=0)\end{array}$ \\
\hline $\begin{array}{l}\mathrm{NF} \\
(\mathrm{n}=9)\end{array}$ & $\begin{array}{c}0 \% \\
(\mathrm{n}=0)\end{array}$ & $\begin{array}{l}11.1 \% \\
(\mathrm{n}=1)\end{array}$ & $\begin{array}{l}66.7 \% \\
(n=6)\end{array}$ & $\begin{array}{c}0 \% \\
(\mathrm{n}=0)\end{array}$ & $\begin{array}{l}22.2 \% \\
(\mathrm{n}=2)\end{array}$ \\
\hline $\begin{array}{l}\text { Totals } \\
(\mathrm{n}=303)\end{array}$ & $\begin{array}{c}16.8 \% \\
(\mathrm{n}=51)\end{array}$ & $\begin{array}{c}20.8 \% \\
(\mathrm{n}=63)\end{array}$ & $\begin{array}{c}55.8 \% \\
(\mathrm{n}=169)\end{array}$ & $\begin{array}{c}2.6 \% \\
(\mathrm{n}=8)\end{array}$ & $\begin{array}{c}4.0 \% \\
(\mathrm{n}=12)\end{array}$ \\
\hline
\end{tabular}


TABle A4

Chrétien Appointments 1993-2003 (RZ Model)

\begin{tabular}{|c|c|c|c|c|c|}
\hline & \multicolumn{2}{|c|}{$\begin{array}{c}\text { Party in } \\
\text { Power Involvement }\end{array}$} & \multirow[t]{2}{*}{$\begin{array}{l}\text { No Known } \\
\text { Affiliation }\end{array}$} & \multicolumn{2}{|c|}{$\begin{array}{l}\text { Opposition } \\
\text { Involvement }\end{array}$} \\
\hline & Major & Minor & & Major & Minor \\
\hline $\begin{array}{l}\mathrm{BC} \\
(\mathrm{n}=71)\end{array}$ & $\begin{array}{l}5.6 \% \\
(\mathrm{n}=4)\end{array}$ & $\begin{array}{l}7.0 \% \\
(\mathrm{n}=5)\end{array}$ & $\begin{array}{l}80.3 \% \\
(\mathrm{n}=57)\end{array}$ & $\begin{array}{c}1.4 \% \\
(\mathrm{n}=1)\end{array}$ & $\begin{array}{c}5.6 \% \\
(\mathrm{n}=4)\end{array}$ \\
\hline $\begin{array}{l}\mathrm{AB} \\
(\mathrm{n}=62)\end{array}$ & $\begin{array}{c}19.4 \% \\
(\mathrm{n}=12)\end{array}$ & $\begin{array}{c}32.3 \% \\
(\mathrm{n}=20)\end{array}$ & $\begin{array}{c}37.1 \% \\
(\mathrm{n}=23)\end{array}$ & $\begin{array}{c}4.8 \% \\
(\mathrm{n}=3)\end{array}$ & $\begin{array}{c}6.5 \% \\
(\mathrm{n}=4)\end{array}$ \\
\hline $\begin{array}{l}\text { SK } \\
(\mathrm{n}=30)\end{array}$ & $\begin{array}{c}40.0 \% \\
(\mathrm{n}=12)\end{array}$ & $\begin{array}{l}30.0 \% \\
(\mathrm{n}=9)\end{array}$ & $\begin{array}{l}26.7 \% \\
(\mathrm{n}=8)\end{array}$ & $\begin{array}{l}3.3 \% \\
(\mathrm{n}=1)\end{array}$ & $\begin{array}{c}0 \% \\
(\mathrm{n}=0)\end{array}$ \\
\hline $\begin{array}{l}\mathrm{MB} \\
(\mathrm{n}=24)\end{array}$ & $\begin{array}{c}41.7 \% \\
(\mathrm{n}=10)\end{array}$ & $\begin{array}{l}25.0 \% \\
(\mathrm{n}=6)\end{array}$ & $\begin{array}{l}29.2 \% \\
(\mathrm{n}=7)\end{array}$ & $\begin{array}{c}0 \% \\
(\mathrm{n}=0)\end{array}$ & $\begin{array}{c}4.2 \% \\
(\mathrm{n}=1)\end{array}$ \\
\hline $\begin{array}{l}\text { ON } \\
(n=178)\end{array}$ & $\begin{array}{c}9.0 \% \\
(\mathrm{n}=16)\end{array}$ & $\begin{array}{c}36.5 \% \\
(\mathrm{n}=65)\end{array}$ & $\begin{array}{c}52.2 \% \\
(\mathrm{n}=93)\end{array}$ & $\begin{array}{c}0 \% \\
(\mathrm{n}=0)\end{array}$ & $\begin{array}{l}2.2 \% \\
(\mathrm{n}=4)\end{array}$ \\
\hline $\begin{array}{l}\mathrm{QC} \\
(\mathrm{n}=111)\end{array}$ & $\begin{array}{c}10.8 \% \\
(\mathrm{n}=12)\end{array}$ & $\begin{array}{c}11.7 \% \\
(\mathrm{n}=13)\end{array}$ & $\begin{array}{c}77.5 \% \\
(\mathrm{n}=86)\end{array}$ & $\begin{array}{c}0 \% \\
(\mathrm{n}=0)\end{array}$ & $\begin{array}{c}0 \% \\
(\mathrm{n}=0)\end{array}$ \\
\hline $\begin{array}{l}\mathrm{NB} \\
(\mathrm{n}=22)\end{array}$ & $\begin{array}{l}63.6 \% \\
(\mathrm{n}=14)\end{array}$ & $\begin{array}{l}27.3 \% \\
(\mathrm{n}=6)\end{array}$ & $\begin{array}{l}9.1 \% \\
(\mathrm{n}=2)\end{array}$ & $\begin{array}{c}0 \% \\
(\mathrm{n}=0)\end{array}$ & $\begin{array}{c}0 \% \\
(\mathrm{n}=0)\end{array}$ \\
\hline $\begin{array}{l}\mathrm{NS} \\
(\mathrm{n}=30)\end{array}$ & $\begin{array}{l}13.3 \% \\
(\mathrm{n}=4)\end{array}$ & $\begin{array}{c}33.3 \% \\
(\mathrm{n}=10)\end{array}$ & $\begin{array}{c}53.3 \% \\
(\mathrm{n}=16)\end{array}$ & $\begin{array}{c}0 \% \\
(\mathrm{n}=0)\end{array}$ & $\begin{array}{c}0 \% \\
(\mathrm{n}=0)\end{array}$ \\
\hline $\begin{array}{l}\mathrm{PE} \\
(\mathrm{n}=7)\end{array}$ & $\begin{array}{l}100.0 \% \\
(\mathrm{n}=7)\end{array}$ & $\begin{array}{c}0 \% \\
(\mathrm{n}=0)\end{array}$ & $\begin{array}{c}0 \% \\
(\mathrm{n}=0)\end{array}$ & $\begin{array}{c}0 \% \\
(\mathrm{n}=0)\end{array}$ & $\begin{array}{c}0 \% \\
(\mathrm{n}=0)\end{array}$ \\
\hline $\begin{array}{l}\mathrm{NF} \\
(\mathrm{n}=18)\end{array}$ & $\begin{array}{l}27.8 \% \\
(\mathrm{n}=5)\end{array}$ & $\begin{array}{l}27.8 \% \\
(\mathrm{n}=5)\end{array}$ & $\begin{array}{l}33.3 \% \\
(\mathrm{n}=6)\end{array}$ & $\begin{array}{l}5.6 \% \\
(\mathrm{n}=1)\end{array}$ & $\begin{array}{c}5.6 \% \\
(\mathrm{n}=1)\end{array}$ \\
\hline $\begin{array}{l}\text { Totals } \\
(\mathrm{n}=553)\end{array}$ & $\begin{array}{c}17.4 \% \\
(\mathrm{n}=96)\end{array}$ & $\begin{array}{c}25.1 \% \\
(\mathrm{n}=139)\end{array}$ & $\begin{array}{c}46.1 \% \\
(\mathrm{n}=255)\end{array}$ & $\begin{array}{c}1.1 \% \\
(\mathrm{n}=6)\end{array}$ & $\begin{array}{c}2.5 \% \\
(\mathrm{n}=14)\end{array}$ \\
\hline
\end{tabular}

